\title{
The Effect of Practices of Green Human Resource Management Based on Teaching Faculties in Chennai City
}

\author{
R. Bhagyalakshmi, M. Priyanka
}

\begin{abstract}
Educational Institutions are increasingly becoming in the know of the importance and combining management of environment and Human Resource management and the same is coined as Green Human Resource management Practices. Green HRM is brought into play along with the policies and practices to promote the sustainable use of resources within the institution. It promotes to maintain and sustain environment. It involves human resource initiative to support sustainable practices and tends to increase the teaching faculties' responsiveness and commitments on the issues of sustainability. Green HRM on implementation can enhance Institution reputation. Green HRM will play a significant role in making the teaching faculties in the know of matters for showing care in us of scarce resources besides prevent the environment from getting contaminated, help in coordinating and reducing waste and avoidable carbon. The instant concentrates on issues influencing the teaching faculties to practice Green Human Resource Management and the effect of Green Human Resource Management in working skill of the teaching faculties. Much needed hypotheses have been formulated based on the objectives of this study. A well structured questionnaire was distributed in order to elicit the views for the purpose of Primary data and the respondents are the teaching faculties of various educational institutions.
\end{abstract}

Keywords : Green Human Resource Management, GHRM, Green HRM Practices, Impact of Green HRM, Green HR, Teaching Faculties.

\section{INTRODUCTION}

Green Human Resource Management has come to occupy a pivotal position in the present research study since there is an imperative need towards attaining awareness of environmental and sustainable development on day to day basis is gaining currency all round the globe. As is known, India's has assured to sink carbon emissions and moves towards competent measures which has gained global recognition. Further, India is one of the emergent countries in Education. Educational Institution is the place where young generations look forward to Discipline, Values, Ethics and knowledge. Tamil Nadu is one of the states in India have different variety of culture-based Education. Also Chennai is

Revised Manuscript Received on December 05, 2019

* Correspondence Author

Dr. R. Bhagyalakshmi*, Assistant Professor, PG \& Research Department of Commerce, Government Arts College for Men, Nandanam, Chennai, India.

M. Priyanka, Research Scholar, Government Arts College for Men, Nandanam, Chennai, India. one of the thickly populated districts in Tamil Nadu, numerous Higher Educational Institutions are well spread over the city of Chennai. People from across the country throng Chennai to gain the course study at an affordable cost and to avail the diversity of courses. It is also found that many Institutions indulge in enormous utilization of carbon footprints to their regular course of work, which is harmful to the comprehensive environment. In recent times many corporate companies, Financial Institutions like banks, Educational institutions are creating initiatives towards the Environmental friendly activities which are called Green practices. This practice helps them to attain the (Corporate) Social Responsibility or Environmental Responsibility.

Every Educational Institution implements Green Practices with several objectives - to build their reputation, help in the process of employee retention, in the interest of social responsibility, to augment admissions for various courses offered by them and to optimize the efficiency of teaching faculties. In order to become environment friendly, various educational institutions were organizing various practices like of use of computers, internet, websites, emails, Audio visual equipments, projectors, mobile phones etc., but the very process demands a high level of management initiative and skill development among the teachers of the institutions as it is imperative on their part to practice in their day to day academic life. The entire process will have a huge impact on the competition front with other major institutions. Thus it is a process of Transformation of HRM activities from manual pattern to automated technology.

\section{NEED FOR THE STUDY}

The very imperative need for the present research is to discus concept of Green HRM and suggest ways and means for implementing the practices and how to make the faculties adapt the same. Further, the paper has made an earnest attempt to study about the extent of learning and implementing the working skill by the various teachers covered by the study as regards Green HRM in Chennai city.

\section{STATEMENT OF THE PROBLEM}

The primary purpose of this study is to develop a research framework and to determine the predominant factors influencing the teaching faculties to practice Green 
Human Resource Management practices and the ways and means to measure the effect of Green human resource management on working skill of the teachers.

\section{OBJECTIVES OF THE STUDY}

- To evaluate the various Green Human Resource Management practices implemented in educational institutions.

- To identify the factors influencing the teaching faculties in the matter of practising Green Human Resource Management.

- To evaluate the impact of Green Human Resource Management on the working skill of the teaching faculties.

\section{HYPOTHESES OF THE STUDY}

There is bound to be a significant relationship between Impact of Green HR practices attained by the Teaching Faculties and their working skill of the Educational Institutions

$>$ Further, there ought to be a significant relationship between factors influencing the teaching faculties to practice and its impact on Green Human Resource Management.

\section{RESEARCH METHODOLOGY}

\section{A. Nature of the Study}

The present study is on Green Human Resource Management Practices among the Teaching Faculties with Special Reference to Chennai city.

\section{B. Research Design}

The study is empirical in nature and is based on Primary and Secondary Data. It is mainly based on primary data collected through well structured and standardized questionnaires which contained posers placed on a five-point Likert scale. The secondary data was obtained from relevant publications including journals, periodicals, articles, research papers, web sites.

\section{Sample size and Design}

A sample size of 150 respondents is taken for the present study. From among the 150 questionnaires, only 140 respondents returned the filled-in questionnaire. Hence, the sample the study is based on 140 respondents. The Sample Design aims at ascertaining the distinctive features of the Green Human Resource Management Practices among the Teaching Faculties. Further, Convenience sampling was adopted to collect the data from the respondents for the present study. The result showed that the statements included in the questionnaire possess high reliability of $96.2 \%$ with Cronbach's Alpha Co-efficient of 0.931.

\section{Period of the study}

The data collected during the period 2018- 2019 are analysed and interpreted with necessary statistical tools. The target population for this study area is teaching faculties of
Educational Institutions in the city of Chennai.

\section{LIMITATIONS OF THE STUDY}

$>$ The sample size of the study is limited to only the Teaching faculties.

$>$ The selected sample size is small as compared to the population.

$>$ The research study and the data collected are limited to only Chennai district of Tamil Nadu.

$>$ The findings of the study cannot be generalized for every District in Tamil Nadu.

\section{Statistical Techniques}

The techniques used have been -Percentage Analysis, Mean based ranking, Chi-Square test, Factor analysis and Multiple Regression.

\section{REVIEW OF LITERATURE}

Sana Arz Bhutto, Auranzeb (2016) "Effects of Green Human Resources Management on Firm Performance: An Empirical Study on Pakistani Firms" - The paper explores the effect of Green Human Resources in terms of selection, learning, training and development for efficacious performance in Pakistan. Respondents from 376 firms were drawn and the collected data was analysed with SPSS including Multiple Regression Analysis in order to analyse the impact of Green Human Resources Management in the areas like recruitment, training and development leading to performance. This study proved that Environment and Protection can be measured by studying waste management, pollution control, recycling and reducing environmental discharges. The study also found that such practices are to be applied in the long run for better system management so as to identify the effect on HRM issues. The study also has found out that the extent and depth of HRM practices are to be measured for better development. Such innovative steps would augur well for policy framing, setting objectives of firms and in achieving organizational performance. The study concludes that not only HRM practices in the matter of recruitment and training etc., play a pivotal role to achieve environmental performance but also that such measures are quite for selection and training of employees in the movement in the direction of sustenance of growth. Thus it gives vibrancy to the organization in terms of their performance and attitude towards the organization. The study finally concludes that HRM practices are very much imperative in the process of achieving and sustenance of environmental performance.

Ali Halawi, WaelZaraket,(2018) "Impact of Green Human Resource Management on Employee Behaviour" This study focuses its attention from the point of view of stakeholders who look forward to the implementation of Green HRM in the organization. In the light backdrop of growing 
disoriented external influences and challenges by the society in Lebanon and the matter of assessing the same and thus appealing to the stakeholders was the crux of the study. The result of exploration of the study is that Lebanese private companies can have a better advantage over their counterparts who put up stiff competition if the Green HRM activities are implemented.

The study found out ways and means to do away with employee's attrition and thus it was a major cause for the implementation. The study concludes that practice of Green HRM coupled with measures by way of providing incentives for employees would provide a better platform for the companies to prove their mettle and thus earn the patronage of funding agencies by way of tax exemptions, necessary legislation and financial assistance etc., The study concludes that Green HRM practices are very much pertinent in the overall growth of the Universities and to derive all the benefits that accrue.

Yong Joong Kim, Woo GonKim, Hyung-Min Choi, KulladaPhetvaroon (2019) "The effect of green human resource management on hotel employees' eco-friendly behaviour and environmental performance" - This study which was done when not much of pioneering research had undergone in hotel industry and the area of research was with lot of pasture. The study aimed and explored the need to develop the attitude and behavioural sense of workers towards environmental issues through adopting Green HRM measures. The study has established that there has been a sense of commitment and behaviour of the employees of hotel industry. It was in this in line of thinking that the study finally suggests that the apex level management should evolve their policies well through Human Resources departments so as to implement Green HRM practices in order to augment growth and development.

\section{DATA ANALYSIS AND INTERPRETATION}

The collected data was analysed and the following Tables depict the analysis and interpretation based on the analysis.

Table 1: Demographic Profile of Teaching Faculties

\begin{tabular}{|c|c|c|c|c|c|c|c|c|}
\hline Profile & \multicolumn{8}{|c|}{ Groups } \\
\hline Gender Group & \multicolumn{4}{|c|}{$\begin{array}{c}\text { Male } \\
78(55.7 \%)\end{array}$} & \multicolumn{4}{|c|}{$\begin{array}{c}\text { Female } \\
62(44.3 \%)\end{array}$} \\
\hline $\begin{array}{c}\text { Education } \\
\text { Qualification }\end{array}$ & $\begin{array}{c}\text { M.com } \\
18(12.9 \%)\end{array}$ & $\begin{array}{c}\text { MA } \\
24(17.1 \%)\end{array}$ & $\begin{array}{c}\text { M.Sc } \\
16(11.4 \%)\end{array}$ & $\begin{array}{c}\text { M.Phil } \\
15(10.7 \%)\end{array}$ & $\begin{array}{c}\text { Ph.D } \\
17(12.1 \%)\end{array}$ & $\begin{array}{c}\text { NET } \\
20(14.3 \%)\end{array}$ & $\begin{array}{c}\text { SELT } \\
17(12.1 \%)\end{array}$ & $\begin{array}{c}\text { Others } \\
13(9.3 \%)\end{array}$ \\
\hline Position & \multicolumn{4}{|c|}{$\begin{array}{c}\text { Assit. Professor } \\
70(50 \%)\end{array}$} & \multicolumn{4}{|c|}{$\begin{array}{c}\text { Assot. Professor } \\
70(50 \%)\end{array}$} \\
\hline Monthly Income & \multicolumn{2}{|c|}{$\begin{array}{c}\text { Upto } 20,000 \\
37(26.4 \%)\end{array}$} & \multicolumn{2}{|c|}{$\begin{array}{c}20,001 \text { to } 50,000 \\
34(24.3 \%)\end{array}$} & \multicolumn{2}{|c|}{$\begin{array}{c}50,001 \text { to } 1,00,000 \\
31(22.1 \%)\end{array}$} & \multicolumn{2}{|c|}{$\begin{array}{c}\text { More } 1,00,000 \\
38(27.1 \%)\end{array}$} \\
\hline Knowledge on Green HRM & \multicolumn{4}{|c|}{$\begin{array}{c}\text { Yes } \\
70(46.7 \%)\end{array}$} & \multicolumn{4}{|c|}{$\begin{array}{c}\text { No } \\
80(53.3 \%)\end{array}$} \\
\hline
\end{tabular}

Table 1 shows the demographic characteristic of the respondents. Sizable number of respondents are males with PG qualification working in identical position of Assistant and Associate professors and earning a very decent income of more than 1 lakhs and who have no knowledge on Green HRM.

Table 2: Factorisation of Working Skills of Teaching Faculty (WSTF) Variables

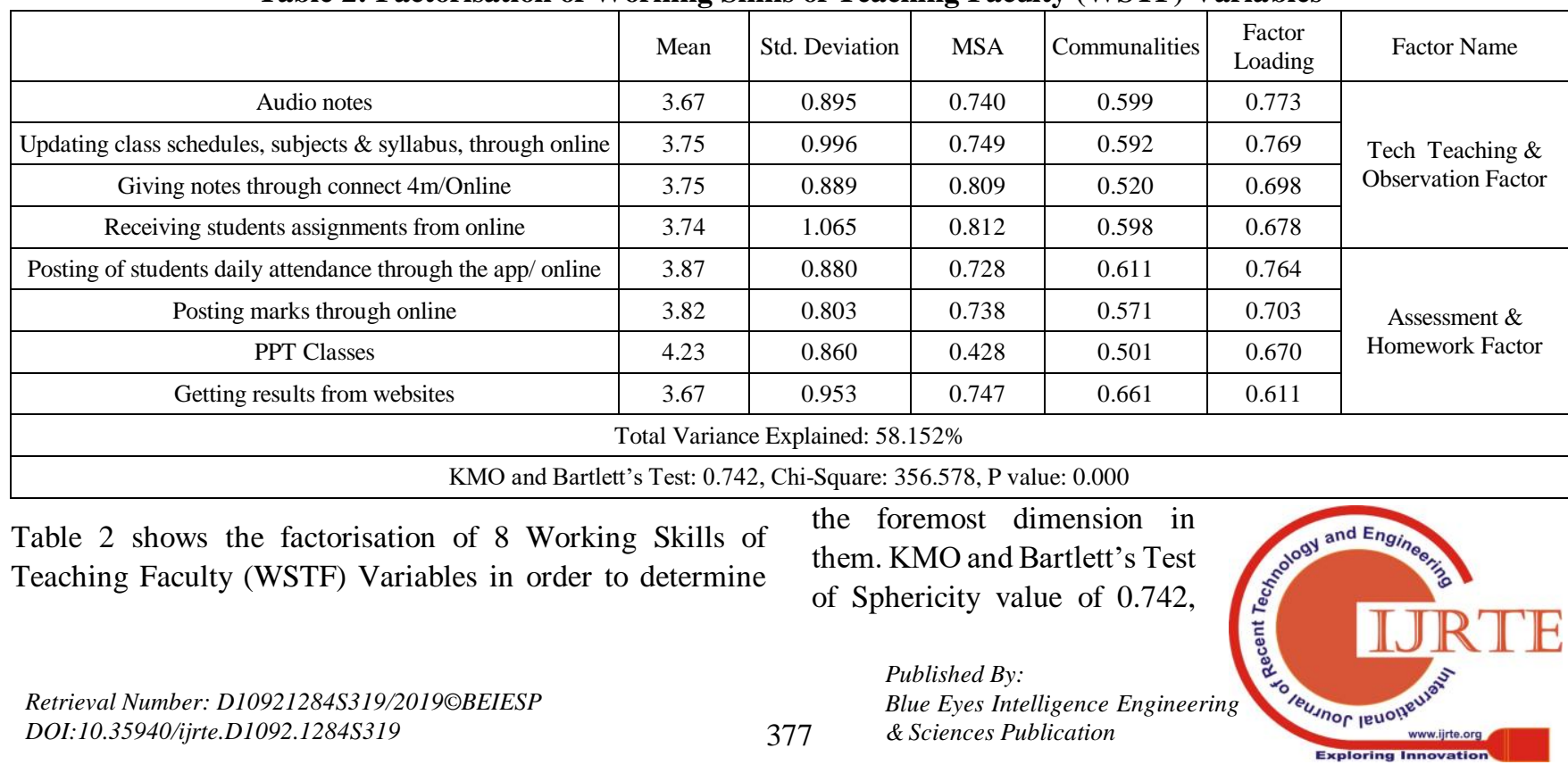


Chi-square value of 356.578 with df of 125 and P-value of 0.000 indicates factorizing can be applied to $8 \mathrm{WSTF}$ variables. The mean value is a robust measure of its standard deviation as mean value is greater than to their standard deviation values.

The communalities values range between 0.501 to 0.661 and
MSA range value from 0.428 to 0.812 , hence factorizing can be applied on 8 WSTF variables. Out of 11 WSTF variables 2 factors have been extracted namely Tech Teaching \& Observation Factor (TTOF) and Assessment \& Homework Factor (AHF) together these factors explain $58.152 \%$ total variance in those 8 WSTF variables.

Table 3: Factorisation of Green HRM Practices followed by College Management (GHRMPCM) Variables

\begin{tabular}{|c|c|c|c|c|c|c|}
\hline & Mean & Std. Deviation & MSA & Communalities & $\begin{array}{l}\text { Factor } \\
\text { Loading }\end{array}$ & Factor Name \\
\hline Online Communication (circulars) & 3.71 & 0.966 & 0.757 & 0.716 & 0.823 & \multirow{3}{*}{$\begin{array}{c}\text { Notification and } \\
\text { Loyalty Factor(NLF) }\end{array}$} \\
\hline College transport to reduce pollution & 3.83 & 0.974 & 0.812 & 0.695 & 0.804 & \\
\hline Digital library & 3.77 & 0.928 & 0.793 & 0.640 & 0.783 & \\
\hline Biometric(Attendance) & 3.6 & 0.92 & 0.758 & 0.677 & 0.800 & \multirow{4}{*}{$\begin{array}{l}\text { Automation and } \\
\text { Resources } \\
\text { Channelizing } \\
\text { Factor(ARCF) }\end{array}$} \\
\hline Electronicfiling & 3.77 & 0.984 & 0.782 & 0.609 & 0.772 & \\
\hline Recycling \&Waste management & 3.73 & 0.967 & 0.801 & 0.643 & 0.767 & \\
\hline Utilization of Solar panel (alternate source to electricity) & 3.79 & 0.952 & 0.816 & 0.521 & 0.550 & \\
\hline \multicolumn{7}{|c|}{$\begin{array}{ll}\text { Total Variance Explained: } 64.284 \% \\
\end{array}$} \\
\hline \multicolumn{7}{|c|}{ KMO and Bartlett's Test: 0.788, Chi-Square: 348.077 , P value: 0.000} \\
\hline
\end{tabular}

Table 3 reveals factorisation of 7 Green HRM Practices followed by College Management (GHRMPCM) variables in order to determine the dominant dimension in them. KMO and Bartlett's Test of Sphericity value of 0.788 , Chi-square value of 348.077 with df of 124 and P-value of 0.000 indicates factorizing can be applied to 7 GHRMPCM variables. The mean value is robust measure of its standard deviation as mean value is greater than to their standard deviation values. The communalities values range between 0.521 to 0.716 and MSA range value from 0.757 to 0.816 , hence factorizing can be applied on 7 GHRMPCM variables. Out of 7 GHRMPCM variables 2 factors have been extracted namely Notification \& Loyalty Factor(NLF) and Automation \& Resources Channelizing Factor(ARCF) together these factors explain $64.284 \%$ total variance in those 7 GHRMPCM variables.

Table 4: Significance Influence of Green HRM Practice at College Management (GHRMCM) on Working Skills of Teaching Faculties (WSTF)

\begin{tabular}{|c|c|c|c|c|c|}
\hline \multirow{2}{*}{} & \multicolumn{2}{|c|}{ Unstandardized Coefficients } & Standardized Coefficients & \multirow{2}{*}{ P value } \\
\cline { 2 - 5 } & $\mathrm{B}$ & Std. Error & Beta & 7.828 \\
\hline (Constant) & 11.195 & 1.430 & 0.748 & 0.000 \\
\hline GHRMCM & 0.737 & 0.054 & 0.000 \\
\hline \multicolumn{3}{|c|}{ F value $=187.812$, P value $=0.000$} \\
\hline
\end{tabular}

Table 4 shows the impact of Green HRM Practice at College Management level on overall Working Skills of Teaching Faculties. There is significant and positive influence of GHRMCM on WSTF $\{\mathrm{F}=187.812$, P-value: 0.000$\}$. The multiple correlation coefficients are 0.748 indicating that $55.9 \%$ of variance explained by GHRMCM in WSTF. The beta coefficient value for the impact of GHRMCM influence is 0.737 which identified partial effect over WSTF holding the other variables as constant. The estimated positive value shows that WSTF would enhance by 0.737 for every 1 unit increase in GHRMCM. The beta coefficient is significant at $1 \%$ level.

Table 5: Significance Influence of Personal Profile, Green HRM Practice (GHRMP) and Working Skill Improvement (WSI) on Overall Green HRM Practice at College Management (GHRMCM)

\begin{tabular}{|c|c|c|c|c|c|}
\hline \multirow{2}{*}{} & \multicolumn{2}{|c|}{ Unstandardized Coefficients } & Standardized Coefficients & \multirow{2}{*}{$\mathrm{t}$} & P value \\
\cline { 2 - 6 } & $\mathrm{B}$ & Std. Error & Beta & 3.740 & 0.000 \\
\hline (Constant) & 4.199 & 1.123 & & 10.374 & 0.000 \\
\hline WSI & 0.905 & 0.087 & 0.582 & 6.544 & 0.000 \\
\hline GHRMP & 0.384 & 0.059 & F value $=200.428$, P value $=0.000$ \\
\hline \multicolumn{7}{|c|}{$\mathrm{R}=0.864, \mathrm{R}^{2}=0.747$, Adjusted $\mathrm{R}^{2}: 0.743$} \\
\hline
\end{tabular}

Table 5 reveals that there is a significant and positive impact of GHRMP and WSI on overall GHRMCM \{F=200.428, P-value: 0.000$\}$. The Multiple Correlation Coefficients is 0.864 indicating that $74.7 \%$ of variance explained by WSI and GHRMP on GHRMCM. The beta coefficient value for the impact of WSI influence is 0.905 which identified partial effect over GHRMCM holding the other variables as constant. The estimated positive value shows that GHRMCM would enhance by 
0.905 for every unit increase in WSI. The beta coefficient is significant at $1 \%$ level. The beta coefficient value for the impact of GHRMP influence is 0.384 which determines partial effect over GHRMCM holding the other variables as constant.

The estimated positive value shows that GHRMCM would enhance by 0.384 for every 1 unit increase in GHRMP. The beta coefficient is significant at $1 \%$ level.

Table 6: Relative Importance of Gender Group in Aspects of Working Skill Improvement

\begin{tabular}{|c|c|c|c|}
\hline \multirow{2}{*}{ Working Skill Improvement } & Gender & Mean & Std. Deviation \\
\hline \multirow{2}{*}{ Improves work efficiency } & Male & 4.66 & 0.849 \\
\cline { 2 - 4 } & Female & 3.68 & 0.953 \\
\hline \multirow{2}{*}{ Communication skill is improved } & Male & 3.82 & 0.970 \\
\cline { 2 - 4 } & Female & 4.72 & 1.005 \\
\hline \multirow{2}{*}{$\begin{array}{c}\text { Work can be done on time } \\
\text { Technical knowledge is } \\
\text { developed }\end{array}$} & Male & 4.54 & 0.892 \\
\cline { 2 - 4 } & Female & 3.68 & 0.953 \\
\cline { 2 - 4 } & Male & 4.73 & 0.982 \\
\hline
\end{tabular}

Table 6 shows relative importance of gender groups in Working Skills Improvement. It shows that there is need for improvement in work efficiency by women teaching faculties which is much lower compared to male faculties. Similarly punctuality by women teaching faculties along with technical knowledge are lacking compared to their relative gender groups. But it is found that Communication skills are better for women teaching faculties as compare to men.

\section{CONCLUSION}

The present study has made an earnest attempt to investigate the perception of teaching faculties over the Green HRM initiatives enunciated by the management of the concerned colleges. It has been well found that all colleges have been following PPT classes, daily students attendance and consolidation through online mode, posting marks online, obtaining results online from the declaring agency, compiling students' assignment online, distribution of notes online, updating class schedules, electronic filling of forms, Biometric attendance, recycling and waste management, utilization of solar technique as an alternative to electricity, creation of digital library, transport which is eco friendly, online communication of circulars, sms wherever necessary, planting saplings etc., Interestingly, it was found that male teaching faculties have better performed in the implementation process of Green HRM practices. It is intriguing to note that female faculties are not aware of the practices. Hence, the study concludes and suggests that a better understanding by female faculties and a sustained Green HRM practices by every educational institution in order that the institution gets an overall facelift and development. It is also suggested that teaching faculties the much needed initiative on the part of the management to provide them incentive in their sense of belongingness to the institution and that they cooperate, promote, support and sustain the overall development of Green HRM practices in their institution. It further enhances their self actualization demand which is an important need to be attended to by any management.

\section{REFERENCES}

1. Ali Halawi, WaelZaraket,(2018) "Impact of Green Human Resource Management on Employee Behaviour" Impact of Green Human Resource Management on Employee Behavior Article in Journal of Applied Business Research • September 2018

2. Sana Arz Bhutto, Auranzeb(2016) "Effects of Green Human Resources Management on Firm Performance: An Empirical Study on Pakistani Firms"European Journal of Business and Management ISSN 2222-1905 (Paper) ISSN 2222-2839 (Online) Vol.8, No.16, 2016

3. Yong Joong Kim, Woo GonKim, Hyung-MinChoi, KulladaPhetvaroon (2019) "The effect of green human resource management on hotel employees' eco-friendly behaviour and environmental performance" International Journal of Hospitality ManagementVolume 76, Part A, January 2019,Pages 83-93

4. Kim, S. H.: An Investigation into Hotel Employees' Perception of Green Practices. (2009).

5. Mandip, G.: Green HRM: People management commitment to environmental sustainability. Research Journal of Recent Sciences, ISSN, 2277, 2502. (2012)

6. Nagendra, A., \& Kansal, S.: Reducing Carbon Footprint through Green HRM. SAMAD, 8. (2015).

\section{AUTHORS PROFILE}

Dr. R. Bhagyalakshmi, is a prolific and creative writer, a good orator, an inspiring teacher and an efficient team leader committing her whole life to promotion of teaching, learning, research and extension activities in College education level and serving the below poverty line students. $\mathrm{Dr}$ R. Bhagyalakshmi is the Assistant Professor in Government Arts College for Men,Nandanam, Chennai. Dr R. Bhagyalakshmi was involved in teaching UG,

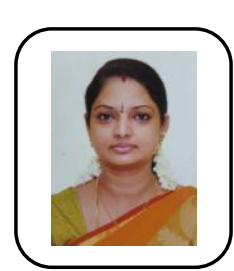
PG,M.Phil., and Ph.D. students for 20 yrs. She has guided 40 MBA projects, 20 Post Graduate project work ,8M.Phil and 4 Ph.D. students. She is having a total experience of 20 years teaching, administration, examiner, and research \& guidance, with specialization in Human Resource Management, Finance and Marketing. She has publications of more than 30 in National and International Journals. Dr. R.Bhagyalakshmihas been conducting a number of short-term courses and national conferences on a regular basis. She has also given guest lectures in various universities. Dr. R. Bhagyalakshmi has her own fascination towards research. She always adore to initiate research on emerging areas HR, Finance and Marketing. She initiated several research activities on Women Empowerment. She is known for her virtues as a wise mentor, friendly teacher, innovative administrator, and visionary leader.

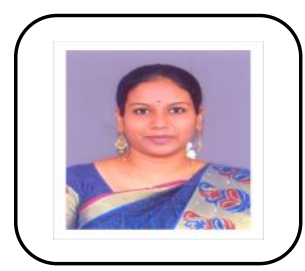

Ms. Priyanka M, is Full time Ph.D Research Scholar under the supervision and guidance of Dr. R. BHAGYALAKSHMI, Government Arts college for Men, Nandanam, Chennai. Published and Presented UGC Listed Articles in three International Conferences and one ISSN Article in National Conference which was conducted by various colleges in Chennai. Participated in two workshops on Research Methodology, SPSS Applications. Have Membership in American Library. 